\title{
Highlights of the Midwinter meetings of the ACRL Board of Directors
}

ACRL actions, January 1991.

The Board of Directors of the Association of College \& Research Libraries (ACRL) met twice during the ALA Midwinter meeting in Chicago: on January 13, 1991, and January 15, 1991.

ALA Office for Research. "The AL,A Office for Research is commended for its high quality work; its excellent support of ACRL's research efforts; and its responsiveness to ACRL's needs," was the text of a resolution passed by the Board. The Board had been invited to comment on the ALA Office for Research in preparation for its review by the ALA Executive Board.

American Indian Library Association. The Board voted to cosponsor the Atlanta Conference program of the American Indian Library Association and the ALA Office for Library Outreach Services Subcommittee on Library Services for American Indian People. The program, "I is not for Indian: Children's Books and Native Americans," will be held on June 29, 1991, 8:00-10:00 p.m.

Board members. Meet and greet your Board members during the ACRL President's Program in Atlanta on July I, 1991. Board members agreed to be available during the information literacy poster sessions following the program.

Conference funding. President Barbara J. Ford announced that the Conference Program Planning Committee for Atlanta decided how to allocate the $\$ 6,000$ that was made available by ALA and ACRL. Ford stated that using a new procedure, the committee members evaluated and ranked all proposals and jointly made the allocation decisions.

Conference scheduling. The Board endorsed three resolutions on the AIA Annual Conference and Midwinter schedule: that the Membership I meeting be returned to its Monday evening time slot; that the official Midwinter dates be listed as Thursday-Thursday and that only meetings of divi- sion executive committees and/or division boards be permitted to occur on the first Thursday of each Midwinter meeting; and that divisions be authorized to schedule and conduct executive committee and/or board meetings on the first Thursday of Annual Conference.

Coalition for Networked Information. ACRL representatives to the Task Force on the Coalition for Networked Information, Thomas J. Michalak and Thomas Kirk, reported to the Board on the progress of the Coalition. Their report will appear in CURL News in April.

College library director mentor program. The Board endorsed a proposal submitted by Larry Hardesty for the College Libraries Section to establish a mentor program to promote better leadership among newly appointed college library directors. Hardesty indicated he would seek grant funding to start the program.

Constitution and Bylaws Committee. The Board approved the bylaws of the Extended Campus Library Services Section and the Women's Studies Section. The Board also approved a change to the Sample Section Bylaws statement.

Endowment policy. The Board adopted an ACRL endowment policy and a separate Choice endowment policy. Upon the recommendation of the Budget and Finance Committee, the Board agreed to establish an ACRL endowment in FY1992 with an initial sum of $\$ 10,000$ and to establish a Choice endowment in FY1992 with an initial sum of $\$ 20,000$. The purpose of the endowments is to generate income to support the development and enhancement of ACRL and Choice programs and activities.

Free expression. The Board endorsed the resolution, "The Universal Right to Free Expression and the Free Flow of Information: a Policy State- 
ment," drafted by the ALA International Relations Committee.

International Relations. A standing committee on international relations was established by the Board. The recommendation for the committee was presented by Maureen Pastine, chair of the ACRL Task Force on International Relations.

Mandated reserve level. The ACRL Board voted to change the mandated reserve level from 50 percent to 40 percent of the average annual expenditures over the three most recently completed years.

National Conference. The Board voted to move the ACRL Sixth National Conference out of Phoenix, Arizona, because of the state's refusal to recognize a state paid holiday in honor of the late Dr. Martin Luther King Jr. The Board accepted a contingency plan to hold the conference in St. Louis, Missouri, on March 25-28, 1992, pending the ALA Executive Board's approval, scheduled for a vote on February 15, 1991. See Barbara Ford's update for details.

Planning Committee. The Planning Committee's review of the Asian and African Section and the Bibliographic Instruction Section were accepted by the Board. The Board also approved a revised charge for the Membership Committee. The new charge reads: "To propose directions, strategies, and programs for recruiting and retaining members; to serve as a link between ACRL and local chapters by coordinating membership promotional effort and disseminating information; to advise ACRL staff on the implementation of membership policies and recruitment activities."

Preconferences. The Board approved requests for three preconferences to be held before the 1992 ALA Annual Conference in San Francisco: the Science and Technology Section will offer a preconference on June 26, 1992, on scientific information delivery; the Rare Books and Manuscripts Section will offer a preconference on June 23-26, 1992, at the University of California at Santa Cruz on special collections and scholarly communication; and the University Libraries Section will offer a preconference on June 25-26, 1992 , focusing on change in university libraries.

Preservation policy. The Board endorsed the ALA Preservation Policy prepared by the ALA President's Committee on Preservation Policy. The policy will be submitted to ALA Council at the ALA Annual Conference in Atlanta, June 1991.

Publications in Librarianship Series. The Board voted to continue ACRL Publications in $\mathrm{Li}$ brarianship, a monographic series published by ALA Publishing. Number 47 in the series, Academic Libraries: Research Perspectives, edited by Mary Jo Lynch and Arthur P. Young, was published in 1990.

Racial and Ethnic Diversity. Upon the recommendation of the Racial and Ethnic Diversity Committee, the Board voted to draft a statement on the following three issues: advocating the need for a continuing commitment by administrators to change and accountability for the recruitment, retention, and advancement of underrepresented groups; recognizing that racism is a barrier individuals and institutions must be sensitive to and must struggle to overcome; and identifying and focusing on ways that academic and research librarians can work to eliminate barriers. The statement will be reviewed by the ACRL Executive Committee during their April 19-20, 1991, meeting.

Recruitment. The Board endorsed the following resolution presented by Anne Beaubien, ACRL vice-president/president elect: "Whereas, the basic health of our profession lies in the background, talents, training, and diversity of its practitioners; and Whereas, library personnel resources, including recruitment, are a major ALA priority; and Whereas, the ACRL Task Force on Recruitment of Underrepresented Minorities has just issued an excellent report with detailed recommendations for action; and Whereas, the theme for the 19911992 ACRL presidential year is recruitment for academic librarianship; and Whereas, it is prudent

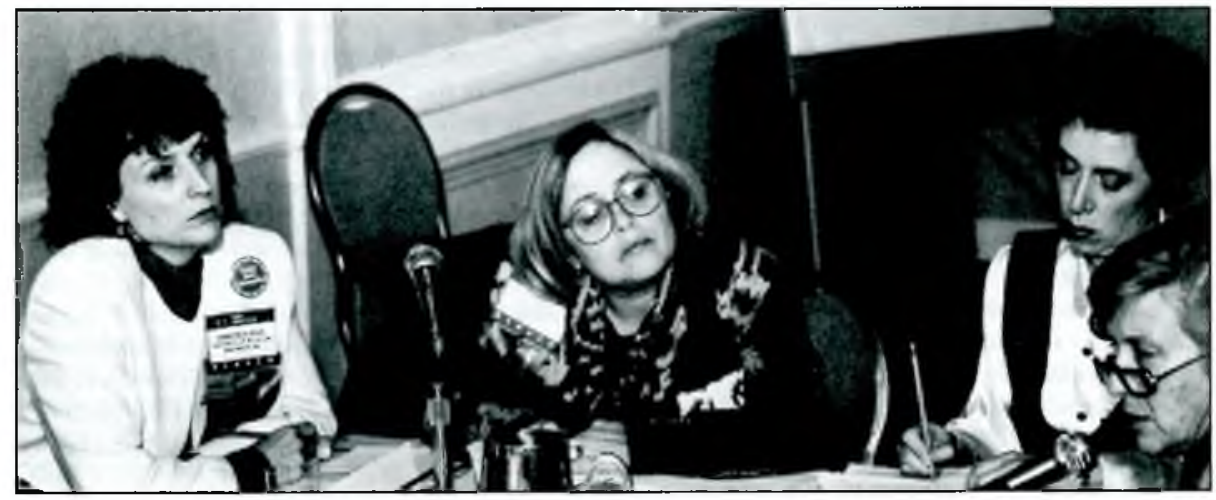


to continue initiatives in this crucial area beyond a single twelve-month period; and Whereas, various competitive grants are available through ALA; Therefore, be it resolved that the ACRL Board authorizes the current president-elect, Anne Beaubien, in conjunction with the appropriate units and staff of ACRL, to write and submit proposals on behalf of the ACRL during 1991 for 1) a World Book-ALA Goals Award, 2) the Baber Research Grant, and 3) a Program Enhancement Request, to secure funding for recruitment-focused research and promotional activities."

Statistics. The Board voted to collect the ACRL university library statistics during the fall of 1991. ACRL has collected and published these statistics every other year since 1978 .

White House Conference on Library and Information Services. In preparation for the upcoming White House Conference on Library and Information Services, the ACRL Task Force on the conference stated that it would meet with all the academic library representatives during the At- lanta Conference. The names of these representatives will also be published in C\&RL News.

Unity resolution. The Board endorsed the following resolution: "We, the AIA division leadership, embrace the diversity of divisional activity, recognize the importance of divisional cooperation, respect the areas of divisional expertise and responsibility as reflected in the divisional function statements, and strongly commit ourselves to effective management of our interdivisional relationships." The resolution was initially adopted at the Concurrent Divisional Executive Committee meeting on November $9,1990$.

World Book-ALA Goal Award. The Board endorsed a World Book-ALA Goal Award proposal suggested by ALA president-elect Patricia Glass Schuman. The proposal is for three intensive workshops for ALA and chapter leaders in media speaker training. The project also provides for the development of materials and issue papers that will "help us get media attention for our profession and the interests of the people we serve."

\section{ACRL vice-president Beaubien announces theme for 1991-92}

ACRL vice-president/president-elect, Anne Beaubien, has targeted recruitment as her theme for her 1991-92 presidential year.

Beaubien, currently ACRL vice-president will assume the presidency in June 1991 after the ALA Annual Conference in Atlanta. She is serving her second term on the ACRL Board of Directors and has chaired a number of ACRL Committees.

"I am concerned about the growing shortage of librarians and $I$ think that a lot of people don't even consider librarianship as a career because they don't really know what we do," said Beaubien. "I think that the work we do as librarians is neat. It's fun, I keep learning new things, and I've never been bored. It is important for us to attract quality people to our profession so that we can start creating the leadership of tomorrow."

Beaubien is particularly interested in recruiting high caliber people with science degrees, social science degrees, and people from racially and ethnically diverse backgrounds - areas in which the profession already has shortages. She plans a multifaceted approach to recruitment including establishing a network of recruiters and development of appropriate materials.

"A people to people approach is what really works. Potential students are more likely to make a career decision based on personal contact than any other method," states Beaubien. "How can we mentor students in our own departments? How can we develop programs to recruit library student workers and paraprofessionals? Are there ways to reach the students on our college campuses? Are there diversity programs we can 'piggy-back' onto for recruitment? How can we best form a network in each state or region? What's the best way to share recruitment ideas and materials?"

Ideas and suggestions for implementing recruitment at the local level should be sent to: Anne Beaubien, 106 Hatcher Graduate Library, University of Michigan, Ann Arbor.

Beaubien is Head of Cooperative Access Services at the University of Michigan Library which includes two services she created-MITS, a feebased library service for businesses and 747-FAST, a campus delivery service of library materials to faculty - and Interlibrary Loan. Previously she was a librarian in the Graduate Library Reference Department at the University of Michigan where she created a bibliographic instruction program for faculty and graduate students.

Beaubien is the recipient of the Women of the Year Award from the Ann Arbor Business and Professional Women's Club as well as the Distinguished Alumnus Award from the School of Information Studies at the University of Michigan. A frequent contributor to professional journals in the areas of information services, database searching and teaching in academic libraries, she is the author of Learning the Library (R. R. Bowker, 1982). 